\title{
Discourse, agency, and social license to operate in New Zealand's marine economy
}

\author{
Mark J. Newton ${ }^{1}$, Trisia A. Farrelly ${ }^{2}$ and Jim Sinner ${ }^{1}$
}

\begin{abstract}
The construction of discourse through choice of wording and sentence structure can affect power relations between people and groups. Social license to operate (SLO), broadly defined as the public's acceptance or approval of a company and its operations, is an emergent concept in New Zealand's marine economy. The way the public discourse around SLO is constructed and communicated can empower some at the expense of others, whether deliberately or inadvertently. This study employed critical discourse analysis to investigate how SLO is used in public documents relating to commercial activities in New Zealand's marine environment between 1996 and 2017. Specifically, the study explores the implied power relations between government, industry, New Zealand's Indigenous tribes (hereafter, iwi), communities, and other stakeholders. We find that industry and central government dominate SLOrelated public discourse, and they frequently vest SLO agency with industry rather than community groups, iwi, or the wider public. Indeed, iwi are largely absent from the SLO discourse in public documents. Definitions of SLO vary extensively across the documents and are largely captured by industry and central government. We conclude that New Zealand's marine SLO public discourse empowers industry at the expense of communities and the public, contrary to the notional intent of the concept.
\end{abstract}

Key Words: aquaculture; blue economy; corporate social responsibility; deep sea mining; fisheries; oil and gas; power; public documents

\section{INTRODUCTION}

The social and ecological transformation envisaged by the concept of a blue economy requires that marine enterprises have a "social license to operate" (SLO; Ocean Governance 2018). Social license to operate refers to communities' acceptance or approval of a company and its operations (Thomson and Boutilier 2011, Moffat and Zhang 2014). The origin of the term is attributed to Canadian and Australian mining industries during the 1990s to indicate that, even if a company holds the appropriate legal permits, its operations are at risk if local communities have a low opinion of the company (Gunningham et al. 2004). The application and study of SLO has since expanded worldwide to include other industries inter alia wind energy (Hall 2014), forestry (Edwards et al. 2016), farming (Williams and Martin 2011), oil and gas (Smits et al. 2017), and marine industries (Kelly et al. 2017).

Theoretically, by bringing community concerns into companies' decision-making, and by communities' gaining agency to grant or withhold SLO, the concept offers an altogether new model of meaningful community participation and empowerment in natural resource governance. On the other hand, where SLO is used cynically by companies as a tool to achieve market advantage while silencing communities (see, e.g., Bice 2014), the concept becomes something akin to "greenwashing," as some critics have labelled the related concept of corporate social responsibility (Hamann and Kapelus 2004, Banerjee 2008, Fleming and Jones 2013).

Thus, the way in which SLO is conceptualized, defined, and used in public discourses can result in vastly divergent outcomes for the very communities the term is notionally intended to serve. A discourse is a way of apprehending the world in the spoken or written word. It is a social boundary defining what can or cannot be expressed about a matter. Those who adhere to similar discursive forms may thus draw shared meaning from otherwise disparate bits of information (Dryzek 2013). Discourse analysts assume that language choices are not accidental or random, and that discourse reflects existing power relationships (Hall 2014). Discourse conditions people's perceptions and advances some interests while suppressing others (Phillips and Hardy 2002). In this way, it renders some people more compliant and governable (Foucault 1980, as cited in Dryzek 2013). The analysis of discourse examines how "placement of people in different social positions, with accompanying divergences of interest, leads them to have different and sometimes conflicting perspectives, articulated in different vocabularies ("discourses")" (Harwood 1988:99). The language used to talk about SLO, then, both reflects and affects the power and social relations implicated in the term and its usage (Fairclough 2013).

Accordingly, discourse analysts are beginning to examine the way the term is used and the corresponding implications for power relations between industry and communities. For example, Owen and Kemp (2013) suggest that SLO has emerged as an industry tool to manage community opposition. While noting its shortcomings, Harvey and Bice (2014), amongst others, continue to argue for SLO as a progressive and democratic concept involving trust-building and "collaborative moderation." Parsons et al (2014) find that the term is used by companies to downplay conflict, and that "while social license potentially represents a shift in power relations, this shift is constrained by discursive pressures to legitimize mining operations, to restrict social license issues to the local level, to minimize regulatory impositions, to marginalize dissent, and to manage reputation" (Parsons et al. 2014:83). This is echoed by Meesters and Behagel (2017) who describe discursive language used by a mining company to deny responsibility for harm to Mongolian communities. They also argue that SLO fails to implement the concept of free and prior informed consent. Thus, whether the concept of SLO serves to empower communities and achieve more participatory and democratic governance of commercial activity, or acts as a cynical 
device for industry to defuse opposition while proceeding with business as usual, comes down to companies' actions, and the intentions underlying those actions may be revealed through discourse analysis.

\section{Social license to operate in marine contexts}

The increasing use of SLO in industry discourses has now reached marine contexts (Kelly et al. 2017, Mather and Fanning 2019). This has brought calls for the study of SLO as related to marine industries given differences in the geographical proximity of communities and stakeholder networks (Mather and Fanning 2019), and as the involvement of communities in marine management lags that of terrestrial industries (Kelly et al. 2017). Although SLO has appeared in marine academic articles since at least 2008 (e.g., Boughen et al. 2008, Hobday et al. 2015, Richert et al. 2015, Voyer et al. 2015), it was years until studies specifically explored the nature and implications of the use of SLO, and marine-focused SLO studies remain few in number (Kelly et al. 2017).

Much of the marine SLO research to date has focused on the aquaculture industry, for example, Baines and Edwards's (2018) study of the importance of relationships to SLO in New Zealand aquaculture, and Billing's (2018) analysis of public comments on applications for new finfish farms in Scotland. Billing's (2018) study found that a few individuals can shape public opinion about the acceptability of salmon farms. Social license of salmon aquaculture was also studied in Tasmania, Australia, in which authors concluded that a balance should be struck between stakeholder views and those of aquaculture businesses (Leith et al. 2014).

Cullen-Knox et al. (2017) studied the influence of SLO on marine governance, although they do not cite actual use of the term SLO in their Australian case studies. Describing cases where activism on social media outpaced formal policy processes, they concluded that "the political response appears to be lagging in its ability to appropriately capture and harness this [SLO] movement" (CullenKnox et al. 2017:75). Voyer et al. (2015) contrasted management and stakeholder engagement at two marine protected areas, finding that community trust in management and industry is important for obtaining social license, and that this can be assisted by recognizing and encouraging diverse opinions of management alternatives. Using discourse analysis to study perceptions of Tasmanian salmon aquaculture, Cullen-Knox et al. (2019) found that the media are giving a voice to previously silent industry players while quietening the voices of environmental groups.

\section{Social license to operate in New Zealand's marine economy}

New Zealand's marine economy contributed $\$ 4$ billion (or $1.9 \%$ ) to New Zealand's \$218 billion gross domestic product in 2013 and generated a further $\$ 3.7$ billion in related industries. The largest contributor to the marine economy is offshore oil and gas (48\%), followed by shipping (24\%), and fisheries and aquaculture $(22 \%)$. The New Zealand Government aspires for economic expansion of the marine economy. Indeed, a goal of the last two successive governments has been a \$1b aquaculture industry by 2025 .

Not all members of New Zealand society are so enthusiastic about plans for marine economic expansion, and the concept of SLO is being invoked in public discourses across all sectors of New Zealand's marine economy. One notable case serves as an example of community opposition putting a stop to marine economic development. Between 1988 and 2001, New Zealand's aquaculture industry experienced rapid expansion. However, the unmitigated growth and other factors led to negative public perceptions of the industry (Tollefson and Scott 2006). In 2014, legal challenges from community and environmental groups to nine proposed salmon farms in the Marlborough Sounds resulted in only four farms being approved. Following this demonstration of the economic risks of a lack of SLO, there have been numerous statements by the government and the aquaculture industry about the importance of improving the industry's SLO. Meanwhile, the government amended legislation to give itself authority to grant permission to the salmon farming company to move farms from existing permitted sites (some of which were not in use) to new sites, taking the decision away from the local government authority.

Unique to New Zealand's marine economy is the role of the Indigenous Māori people, whose place in resource management is based on New Zealand's founding document, the Treaty of Waitangi. The Treaty promised that Māori would enjoy "full exclusive and undisturbed possession" of their lands, forests and fisheries so long as they wished to retain them (Wilson 2018). Given New Zealand's colonial history, many Māori are understandably wary of SLO and the risk of diluting hard-won statutory rights in the management of natural resources. Because the Treaty of Waitangi "[is] a key vehicle by which Māori permit or withhold consent” (Ruckstuhl et al. 2014:304), only Treaty-led relationships, not SLO-based relationships, are likely to be acceptable to Māori on matters of natural resource management. Some iwi (Indigenous Māori tribes of New Zealand) also have significant commercial interests. After individual fisheries quota were introduced in the late 1980s, Māori won a fisheries settlement from the government in 1992 and slowly increased their holdings to now control approximately half of commercial fisheries quota (Bodwitch 2017). Māori leaders have been forceful in asserting that so-called "settlement quota" is unique and cannot be brushed aside by environmental interests claiming a public mandate for a new ocean sanctuary (Iwi Collective Partnership 2016).

Social license to operate is an emergent term in New Zealand, where it is being used by academics, industry, government, and media (Edwards and Trafford 2016) to comment on mining, aquaculture, dairy farming, and forestry (Ruckstuhl et al. 2014). Although some studies have explored SLO in relation to New Zealand's aquaculture industry (Quigley and Baines 2014, Baines and Edwards 2018), and on Māori perspectives on offshore and onshore mining (Ruckstuhl et al. 2014), SLO remains largely unstudied for New Zealand's marine industries.

We use discourse analysis to explore the ways in which various parties are deploying the term SLO in New Zealand's marine economy, and the implications this has for power between these parties. Our wider aim is to highlight where groups and individuals may need to more carefully consider deeper meanings, possible interpretations, and implications for power when the term SLO is deployed in public discourse. This study is timely because of several high-profile community-industry conflicts over marine resource development in New Zealand, the New Zealand government's aspirations for continued marine economic growth, and the increasing use of SLO in the public discourse. Ultimately, 
we hope that our findings can help states, communities, Indigenous groups, and progressive companies to navigate the plasticity and diverse interpretations of SLO, and to significantly improve upon often opaque references to SLO.

\section{METHODS}

Key to the study of power through discourse analysis is the examination of the subtle ways in which what people say and how they say it can vest some actors with agency, often at the expense of others. Agency in this context means "the socioculturally mediated capacity to act" (Ahearn 2001:112). Thus, an actor has agency with respect to SLO if they have the capacity to act in a way that will influence SLO. Parsons and Moffat (2014) employed discourse analysis to explore SLO agency in Australian mining company reports and conference proceedings. They found that the ways in which agency relationships were expressed served to maintain existing power relations that favor companies' shortterm economic gains over the environmental and social impacts immediately felt by communities.

Similarly, the definitions used in public discourses also carry implications for power. Who defines a term, as well as the meanings deriving from the definition itself, are important for community participation in governance (Gaventa 2006). In the case of SLO, there is no commonly accepted definition across academia, industry, government, print media, and other contributors to the public discourse (Edwards and Trafford 2016). An emerging discourse can be expected to have multiple definitions as different actors contest meaning. However, for SLO, this ambiguity allows the term to be used cynically to serve powerful interests. For example, studies have found that SLO is often defined in ways that only tell a partial story of SLO, and that governments, activists, and companies use the term opportunistically to serve their own ends (Owen and Kemp 2013, Moffat et al. 2016). Edwards and Trafford (2016) found that SLO is commonly defined in ways that are financially beneficial to an industry or company, instead of acknowledging social elements. Even when companies define SLO in ways that bring social issues to the fore, their strategies often fail to engage stakeholders in developing a shared vision for their community (Owen and Kemp 2013).

Differences between companies' stated understanding of SLO and their stated approaches for advancing SLO also carry implications for power. Although the academic literature proposes a range of approaches for advancing SLO, all converge on developing meaningful, long-term, trust-based relationships with communities (cf. Prno 2013, Baines and Edwards 2018; Boutilier and Thomson 2011, unpublished manuscript, https:// socialicense.com/publications/Modelling $\%$ 20and $\% 20$ Measuring $\%$ 20the $\% 20$ SLO.pdf). For example, Baines and Edwards (2018) suggest that "relational relationships" (those that are longer term, socio-emotional, and intangible), as opposed to "transactional relationships" (shorter term, compensation-based, tangible), are more likely to gain community acceptance and thus SLO. But there are many ways to achieve that. Moffat and Zhang (2014) propose that SLO requires the establishment of trust through high quality community interactions, having a positive social impact in the community, and including communities in decision making. Prno (2013) proposes that companies can achieve SLO by developing relationships, being sustainable in business operations, providing benefits to local communities, and enabling public participation. Other approaches include procedural fairness (Lacey et al. 2016), community engagement (Dare et al. 2014, Edwards and Trafford 2016), free, prior, and informed consent (Grutzner and Salim 2003), and alignment of a company's operations, organizational values, and processes with community expectations (Dare et al. 2014).

Discourse analysis identifies "the sets of ideas, or discourses, used to make sense of the world within particular social and temporal contexts ... [and] ... offers insights into how particular knowledge becomes common sense and dominant while simultaneously silencing different interpretations of the world" (Waitt 2010:217). Critical discourse analysis focuses on how language, through discourse, constructs and maintains power relations (McKenna 2004, Parsons and Moffat 2014). We employed critical discourse analysis to focus on the textual and grammatical use of SLO in the grey literature of New Zealand's marine economy. Through this analytical lens we explored how the syntactic use of SLO vests agency with some actors over others, and the implications this has for power relations between industry, government, iwi, and stakeholders identified as such in the texts.

We analyzed publicly accessible grey literature, i.e., materials and research produced outside of the traditional commercial or academic publishing and distribution channels (Conn et al. 2003). Using internet search engines Google and Factiva, we identified documents that mentioned SLO, referred to one or more commercial marine activities within New Zealand's exclusive economic zone (EEZ), and were published between 1 January 1996 and 17 September 2017. The base year, 1996, was chosen to predate the first use of the term SLO in public discourses (see Boutilier 2014).

Separate internet searches were conducted for the occurrence of the term "social license" (and alternative spelling "licence") with each of 10 different marine industries. Web searches were suspended at the 100th result to consistently limit the searches while allowing enough scope to effectively capture the most relevant grey literature (Collaboration for Environmental Evidence 2013). This generated 2000 search results which, after removing duplicates and applying exclusion criteria, resulted in 99 relevant documents. News media articles written by journalists were excluded, the rationale being that the paraphrasing inherent in news texts alters the sentence structure, which then affects the inferences one can draw from discourse analysis. We also excluded related concepts such as corporate social responsibility because we wanted to focus on the discourse of the term SLO. Although scholarly articles were excluded, two documents relating to large government-funded science programs were included because they are nonacademic texts written for a public audience.

All documents were uploaded to qualitative data analysis software package, NVivo (QSR International Pty Ltd. 2015) for coding. At the outset of the coding process, based on the themes evident in the literature, we chose four lines of inquiry: definitions of SLO, approaches to advance SLO, agency to affect SLO, and status of SLO. Within these lines of inquiry, themes were developed inductively as coding progressed.

For the first line of enquiry, we identified SLO definitions by searching texts for instances where the term was explicitly defined, 
for example, where the text stated "SLO is defined as ..." or "SLO is ..." We specifically analyzed three elements of definition: (1) the source of the definition, (2) the actual definition, and (3) the key concepts present in that definition (hereafter referred to as definitional components).

By establishing these aspects of definitions, we then sought to identify the approaches for advancing SLO, e.g. by gaining trust, developing partnerships, and through education, stated in each text. The purpose of this analysis was to assess the range of approaches of importance to different actors, as revealed by their mention in the discourse. We assume that actors will state the approaches that they are doing, or have observed or experienced. For example, a company is likely to advertise their best efforts to advance SLO. Likewise, a community group will publicly state their experiences of SLO-related interactions whether good or bad. We contend that power is exerted where the stated approaches of one actor or group differ to, or are omitted by, another more powerful actor. For this analysis, all themes emerged organically out of the document analysis, rather than being predefined.

To analyze agency, we interrogated the grammatical structure of sentences and, specifically, identified where an actor was positioned in a sentence in relation to the term SLO. Assigning agency was done using a theme-rheme framework. Theme is the subject of a sentence or point of departure: the thing that the sentence is about (Halliday and Matthiessen 2013). The rheme is the remainder of the message, telling the recipient something about the theme. In English, the theme is always at the start of the sentence and is followed by the rheme (Halliday and Matthiessen 2013).

Following the method of Parsons and Moffat (2014), explicit agency was assigned where the actor occurs in the theme position (Fig. 1). For example, "the community increased social license." Because the actor (in this example, the community) is the subject of the sentence and is in the theme position, the reader is in no doubt about who is initiating action, and so agency is explicit. When the actor occurs in the rheme position, the relationship between actor and action is less direct and agency was deemed less explicit. In some cases, agency was implied when it was unclear who the actor was, for example, "SLO was increased." Agency was deemed absent when no actor was identified, and no agency was implied, for example, "SLO increased."

Fig. 1. Method to determine agency. SLO = social license to operate.

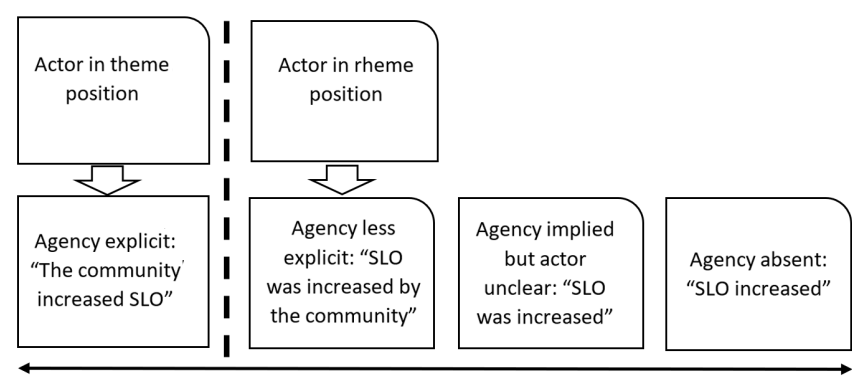

Increasing agency

Decreasing agency
Finally, we assessed the status of SLO as revealed by the use of material process verbs. There are six categories of process verbs: material, relational, mental, verbal, behavioral, and existential (Halliday and Matthiessen 2013). Material process words are "doing" or "happening" verbs. We focus on four categories of material processes, "acquiring," "improving," "maintaining," and "diminishing," to represent various possible stages of SLO, in order to reveal what a given source assumes about SLO status. These stated assumptions may be either empowering or disempowering for groups or individuals depending on their degree of input into, or exclusion from, processes relating to the ongoing negotiation of SLO.

Two of the authors manually coded each text following the methods detailed by Cope (2010). For validation, the two researchers coded five of the same documents in parallel and compared the results. Differences were noted and discussed until consensus was reached. The researchers proceeded to code half of the remaining documents each, working in unison so that any uncertainties could be immediately resolved. They coded the remaining documents separately, after which the third author reviewed and revised the coding with one of the coding team to improve clarity of themes and accuracy of coding.

\section{RESULTS}

Of the 99 documents identified in our literature searches, the first appeared in 2008. The number of documents that mention SLO increased year on year during 2012-2015, peaking at 27 documents. Industry sources have published the most documents $(\mathrm{n}=31)$ mentioning SLO, followed by central government $(\mathrm{n}=$ 27 ), and NGOs ( $n=12$; Table 1$)$, with considerably less frequent usage of the term by iwi $(n=2)$ and local government $(n=2)$. Twenty-five SLO documents were authored by other organizations and individuals, which include scientific research institutes, consultants, collaborative stakeholder groups, think tanks, international organizations, and an independent government commissioner.

Social license to operate has been used in the context of several of New Zealand's marine industries. Documents with a focus on two or more marine industries, termed "marine-general," were the most commonly identified by our search $(n=26$; Fig. 2$)$. Documents relating to oil and gas were the next most common $(\mathrm{n}=25)$, followed by fishing $(\mathrm{n}=19)$, marine aquaculture $(\mathrm{n}=$ $14)$, seafood $(n=5)$, mining and minerals $(n=5)$, and port infrastructure $(n=4)$.

\section{Defining social license to operate}

We analyzed definitions to reveal which actors are contributing definitions to the public discourse of SLO, and the components that make up those definitions. These elements carry important implications for power, in that the definer of a term captures its meaning and shapes public understanding (Gaventa 2006). We found that, of the 99 documents in our sample, 22 offered an explicit definition of SLO, and no two sources defined SLO in the same way. Eight central government documents, eight industry documents, and six other documents defined SLO, while definitions of SLO were not offered by NGOs, local government, or iwi. Of the 22 definitions, we identified 17 definitional components, including environmental performance, iwi acceptance and approval, trust and confidence of communities, best practice, and others (Fig. 3). 
Table 1. Number of documents related to New Zealand's marine industries that mention social license to operate (SLO) by source, 2008-2017.

\begin{tabular}{|c|c|c|c|c|c|c|c|c|c|c|c|}
\hline Source & 2008 & 2009 & 2010 & 2011 & 2012 & 2013 & 2014 & 2015 & 2016 & 2017 & Total \\
\hline Industry & & 1 & & & 2 & 4 & 7 & 8 & 7 & 2 & 31 \\
\hline Central Govt & & & & & & 4 & 8 & 6 & 3 & 6 & 27 \\
\hline Other & 1 & & & & 5 & 6 & 3 & 5 & 5 & & 25 \\
\hline NGO & & & & & 1 & & 1 & 6 & 4 & & 12 \\
\hline Iwi & & & & & & 1 & & 1 & & & 2 \\
\hline Local Govt & & & & & & 1 & & 1 & & & 2 \\
\hline Total & 1 & 1 & & & 8 & 16 & 19 & 27 & 19 & 8 & 99 \\
\hline
\end{tabular}

Fig. 2. Number of documents published by different sources that refer to New Zealand's marine industries, 2008-2017. Iwi = Indigenous Māori tribes of New Zealand.

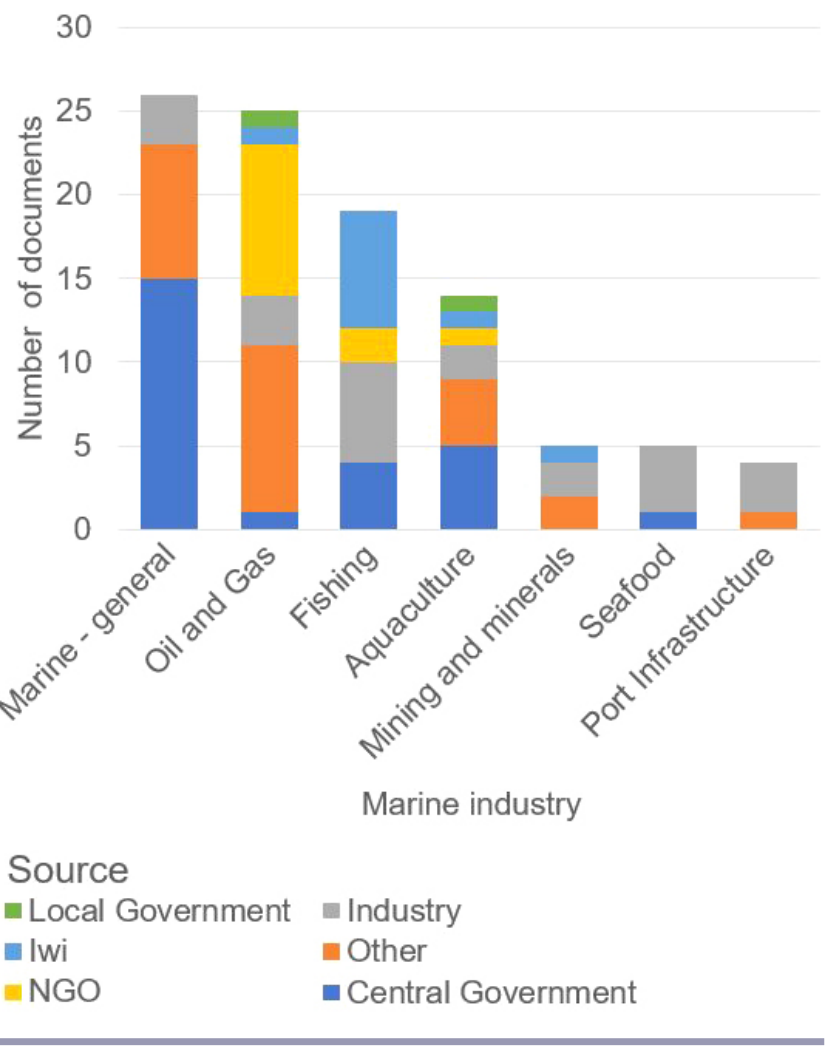

A document from the Sustainable Seas National Science Challenge (Sustainable Seas 2015) offered the most comprehensive definition of SLO, referencing nine of the 17 definitional components. This was followed by a Ministry for Business, Innovation and Employment (MBIE) document, the Sustainable Seas Research Plan (MBIE 2015), which referenced five components. (Note: both documents refer to the project of which this research forms a part, so our research is also part of the discourse.)

Most of the sources that defined SLO mentioned community or stakeholder "acceptance" or "approval" (10 documents). For example, social permissions commonly known as social licence to operate refers to the level of acceptance or approval of for-profit companies that use publicly owned resources by local communities and other stakeholders (McGuinness Institute 2016:4).

More than half $(n=6)$ of the 10 documents that defined SLO in terms of acceptance or approval were authored by central government, most of which $(n=4)$ were from the Ministry for Primary Industry (MPI). Two of the four industry organizations that offered an explicit definition of SLO included acceptance or approval in their definitions. Apart from this, there was no overlap of definitional components between the four industry sources, i.e., they all defined SLO differently. Although relatively few of the documents offered explicit definitions of SLO $(22 \%)$, how the sources interpret and potentially enact SLO may also be further illuminated by how they say SLO has, or might, be advanced.

\section{Approaches for advancing social license to operate}

We analyzed the approaches various sources reported using in relation to SLO to reveal the ways SLO is being implemented. Of the 99 documents, 56 described approaches for advancing SLO, with 16 unique approaches identified in our coding (Table 2). "Communication and engagement' was the most frequently cited, with a total of 32 references. Half of these included terms and phrases synonymous with "inform," "consult," and "collaborate." Industry sources made the most references to "communication and engagement" $(\mathrm{n}=14)$.

Approaches for advancing SLO that referenced "community engagement" as one such approach were often vague. For example, when authors referred to "communication" or "engagement," it was often difficult to determine whether this implied active collaboration and participation with stakeholders on an equal footing, or that information transfer from industry to community was sufficient to satisfy "community engagement," for example, "New approaches to engage the public in accepting change and uptake of new technologies... Early and proactive discussion of new technologies with the community" (National Science Challenges Panel 2013:26 \& 40). The following were rare exceptions:

Appropriate engagement, communication and outreach methods are key to ensuring tangata whenua are actively involved in the Challenge. It is important to the Challenge that tangata whenualiwi Māori are aware that a key outcome is social licence. It is important that 
Fig. 3. Definitional components of social license to operate (SLO) by source. Iwi = Indigenous Māori tribes of New Zealand; MBIE $=$ Ministry for Business, Innovation, $\&$ Employment; MPI = Ministry for Primary Industries.

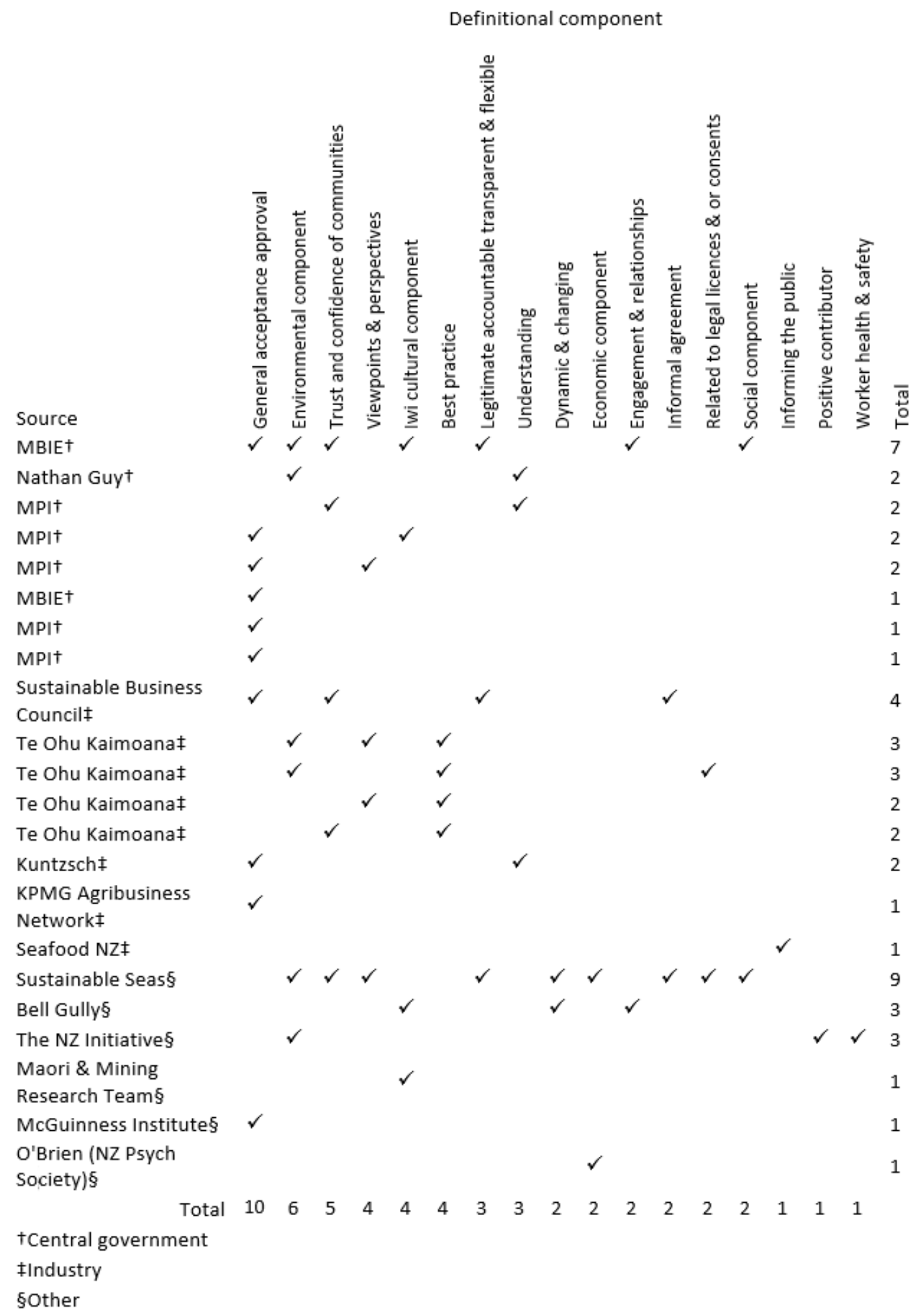


Table 2. Approaches for advancing social license to operate (SLO), by source.

\begin{tabular}{|c|c|c|c|c|c|c|}
\hline Approach & Central Govt & Industry & Local Govt & $\mathrm{NGO}$ & Other & Total \\
\hline Communication \& engagement & 8 & 12 & & 1 & 7 & 28 \\
\hline Environmental sustainability & 5 & 4 & & 1 & 4 & 14 \\
\hline Trust & 5 & 4 & & & 3 & 12 \\
\hline Relationships, partnerships, and social networks & 5 & 6 & & & & 11 \\
\hline Transparency, flexibility, and accountability & 2 & 4 & & & 3 & 9 \\
\hline Iwi engagement and cultural sensitivity & 2 & 2 & & 1 & 2 & 7 \\
\hline $\begin{array}{l}\text { Understanding community (e.g. values, aspirations, } \\
\text { preferences) }\end{array}$ & 2 & 2 & & 1 & 1 & 6 \\
\hline Benefits sharing & & & 1 & & 3 & 4 \\
\hline Monitoring and reporting & & 1 & & & 2 & 3 \\
\hline $\begin{array}{l}\text { Social responsibility (e.g. employment, community } \\
\text { volunteering) }\end{array}$ & 1 & 1 & & & 2 & 4 \\
\hline Strategy & 1 & 2 & & & 1 & 4 \\
\hline Government oversight & & 2 & & 1 & 1 & 4 \\
\hline Charities and sponsorship & 1 & 2 & & & & 3 \\
\hline Worker Health and Safety & & & & & 3 & 3 \\
\hline Giving effect to the Treaty of Waitangi & 1 & 1 & & & & 2 \\
\hline Economic development & 1 & & & & & 1 \\
\hline
\end{tabular}

any potential social licence is not in conflict with aspirations and existing approaches of tangata whenual iwi Māori. Participation in the Challenge will ensure that their mātauranga, culture and experiences are reflected in new frameworks (MBIE 2015:69).

Community engagement including sponsorship, community panels and consultation around resource, environmental and community concerns through real time communications and online information (New Zealand Oil \& Gas 2015:61).

In one document, “community engagement" was presented as merely an instrument to encourage public acceptance of the science underpinning industry activities, rather than primarily to encourage civic deliberation and democratization of the science. In this document, research activities related to SLO were described as "[n]ew approaches to engage the public in accepting change and uptake of new technologies" (National Science Challenges Panel 2013:26).

There were 10 instances where industry proposed that advancing SLO is a matter of communicating "facts" to the public, or where vague references were made to "engaging the public" for the primary purposes of ensuring the public understands so that they will more likely accept the company and their activities. For example,

Social licence is a somewhat technical term which
essentially means successfully getting the facts across to
the public and politicians so they will understand your
operations and approve them or at the very least not
oppose them (Seafood New Zealand 2014).

This approach suggests that gaining SLO is primarily treated as an instrumental process by which industry can manage society in order to clear the path for industrial activity.

\section{Agency and actors}

Agency is important to the examination of power, in that assumptions about agency can empower or disempower some actors at the expense of others. We analyzed which actors are vested with agency over SLO, and by whom, by interrogating the grammatical sentence structure of a text and categorizing agency based on its treatment of actors under the theme-rheme framework.

There were 56 documents that contained statements with explicit or implicit agency in relation to SLO. Of these, 30 gave explicit agency to a specific actor (Table 3), i.e., the actor was in the theme position of the sentence. Industry was the actor most commonly cited as having explicit agency $(\mathrm{n}=14)$. For example, "[i]ndustry can build social licence with more and higher quality information" (MPI 2016:3). Explicit agency was vested with society or communities in five documents. For example, “... society as a whole 'issues' social licence ..." (Sustainable Business Council 2013:4). Explicit agency was also vested in industry and central government $(\mathrm{n}=3)$, iwi $(\mathrm{n}=3)$, a combination of central government and community $(n=2)$, central government $(n=1)$, iwi and community $(n=1)$, and scientists $(n=1)$.

Agency was less explicit in 10 of the 56 instances, with the agent situated later in the sentence, in the rheme position. Consider this example:

Ports of Auckland Ltd will be recognised by our community as a leader in sustainability, thereby granting us with a social licence to operate (Ports of Auckland Limited 2016:5).

This is one of the more complicated examples we encountered, coded as "less explicit/community" because it is "our community" that will undertake the active verb (recognize), yet "our community" is in the rheme position. This is less explicit, and weaker, agency than saying "our community will recognize us." Community was the most commonly cited actor with less explicit agency $(n=6)$, followed by "industry and community" $(n=2)$, industry $(\mathrm{n}=1)$, and iwi $(\mathrm{n}=1)$.

Agency was implicit in 14 instances. That is, some agency is implied but the agent is not clearly stated. In the following 
Table 3. Number of documents that vest agency with different actors in relation to New Zealand's marine industries, by source.

\begin{tabular}{|c|c|c|c|c|c|c|c|c|c|c|c|c|c|c|}
\hline \multirow[b]{3}{*}{ Source } & \multicolumn{14}{|c|}{ Agency and Actor } \\
\hline & \multicolumn{8}{|c|}{ Agency explicit } & \multicolumn{4}{|c|}{ Agency less explicit } & \multirow{2}{*}{$\begin{array}{l}\text { Agency } \\
\text { implicit }\end{array}$} & \multirow[t]{2}{*}{ Total } \\
\hline & Industry & Community & $\begin{array}{c}\text { Industry } \\
\text { and } \\
\text { Central } \\
\text { Govt }\end{array}$ & Iwi & $\begin{array}{c}\text { Central } \\
\text { Govt and } \\
\text { community }\end{array}$ & $\begin{array}{c}\text { Central } \\
\text { Govt }\end{array}$ & $\begin{array}{c}\text { Iwi and } \\
\text { Community }\end{array}$ & Scientists & Community & $\begin{array}{c}\text { Industry } \\
\text { and } \\
\text { Community }\end{array}$ & Industry & Iwi & & \\
\hline Central Govt & 5 & 3 & 3 & & 2 & 1 & & & 3 & 1 & 1 & 1 & 5 & 25 \\
\hline Local Govt & & & & & & & & & & & & & 1 & 1 \\
\hline Industry & 5 & & & 3 & & & & & 3 & 1 & & & & 12 \\
\hline NGO & 2 & 1 & & & & & & & & & & & 3 & 6 \\
\hline Iwi & 1 & & & & & & 1 & & & & & & & 2 \\
\hline Other & 1 & 1 & & & & & & 1 & & & & & 5 & 8 \\
\hline Total & 14 & 5 & 3 & 3 & 2 & 1 & 1 & 1 & 6 & 2 & 1 & 1 & 14 & 54 \\
\hline Percent & & & & & 55.6 & & & & & 17.9 & & & 25 & 100 \\
\hline Total & & & & & 30 & & & & & 10 & & & 14 & 54 \\
\hline
\end{tabular}

example, the reader might surmise that members of the aquaculture industry would create SLO by undertaking reforms.

Creating the social licence for aquaculture has remained elusive and previous aquaculture reforms have not yielded the anticipated results (McPhee 2015:5).

Status of social license to operate

We analyzed actors' assumptions about the status of SLO as revealed by their use of four categories of material process verbs: acquiring, improving, maintaining, and diminishing. In the 84 documents that mentioned material processes in relation to SLO, acquiring was the most frequently mentioned $(n=43,51 \%$; Fig. 4). Acquiring verbs included, for example, "earn" ( $n=17$ sources), "achieve" $(n=9)$, "acquire" $(n=5)$, and "gain" $(n=5)$. Acquiring verbs were most frequently used by "other" organizations and individuals $(n=15)$, followed by central government $(n=14)$, local government $(n=2)$, and iwi $(n=1))$. The frequent use of these verbs indicates that the sources consider that SLO is either yet to be acquired by New Zealand's marine industries, is in the process of being acquired, or has recently been acquired. For example, "consultation with iwi and communities is just one aspect of earning a social licence to operate" (Minter Ellison Rudd Watts 2012:8). (In this and the examples that follow, we have added the emphasis to indicate material process verbs.)

In other instances, "acquiring" verbs were used by NGOs and other organizations to cynically illustrate the way they felt SLO was being sought. For example,

\section{... many would agree that Todd's sponsorship with naming rights represents little more than a way to buy social licencelacceptance within our communities (Climate Justice Taranaki 2016, https://climatejusticetaranaki. wordpress.com/events/).}

"Improving" material processes were next most commonly mentioned, composing nearly a quarter of all mentions $(n=20$, $24 \%$ ). Improving verbs include "build," "improve," and "strengthen." By using these verbs, sources suggest that New Zealand marine companies already possess a degree of SLO and want it to increase. For example, "MPI is also partnering with industry to improve the social licence of the sector..." (MPI 2014:25).
Fewer documents mentioned "maintaining" ( $\mathrm{n}=14,16 \%)$ material processes, using verbs such as "maintain," "retain," and "preserve." Use of these verbs implies that companies possess SLO. The main users of maintaining verbs are industry, central government, and other commentators. For example,

One of the industry's biggest concerns is maintaining social licence. As many of us have consents due for renewal in the next 11-12 years or are applying for new water space, our licence to operate will be tested in the not-too-distant future (Aquaculture New Zealand 2014:10).

Absent from comments relating to maintaining SLO are NGOs, iwi, and local government.

"Diminishing" material processes were the least commonly mentioned of the four $(\mathrm{n}=8,9 \%)$, but were the most common material process mentioned by NGOs and iwi. Verbs associated with diminishing include "erode," "remove," "lose," and "withhold." For NGOs, diminishing material processes were mostly used to declare their own efforts to diminish or revoke the SLO of marine companies. For example,

... we're removing the 'social licence' of fossil fuel companies and chipping away at their source of power (350 Aotearoa 2014, blog, https://thedailyblog.co. nz/2014/02/26/guest-blog-jessie-dennis-from-350-aotearoawestpac-greenwash-and-fossil-fuel-divestment-why-youshould-make-the-switch/).

Industry sources used diminishing material processes on four occasions. In each case, the source referred to hypothetical situations of what could or would happen under certain circumstances or due to certain events and, in some cases, what they are doing or could do to avoid them. For example,

... our social licence to operate would be seriously undermined if we didn't take the initiative and get in front of schools and provide them with factual resources, preferably through a national, co-ordinated programme (Kos 2015).

Central government, local government, and "other" sources did not mention diminishing material processes. 
Fig. 4. Status of social license to operate (SLO) as implied by material process verbs by source.

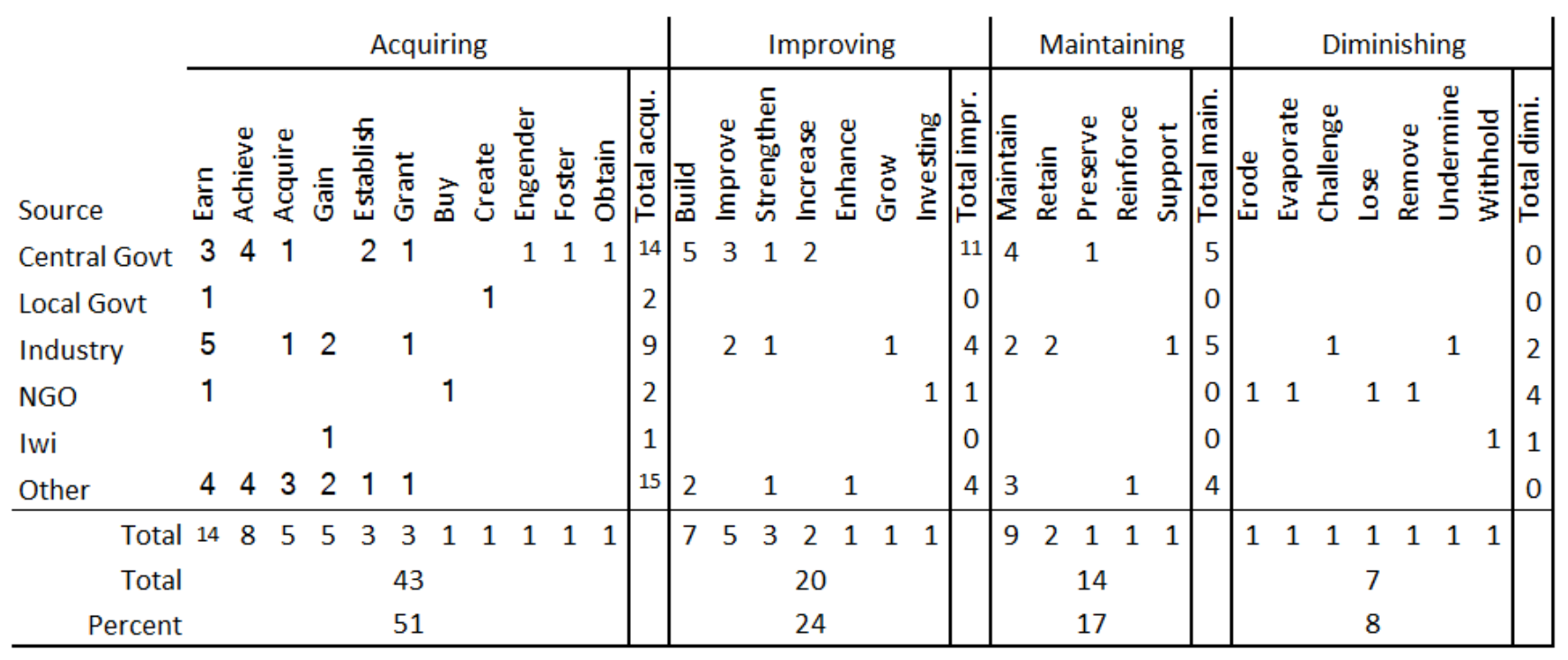

Finally, a source's choice of material process verb implies a particular type of agent. Acquiring, improving, and maintaining verbs generally refer to industry actors, while diminishing verbs mostly refer to community actors. There are exceptions, however; "grant" is an acquiring verb but the implied actor is community, whereas "lose" is a diminishing verb with industry as the implied actor. Other verbs such as "reinforce" and "evaporate" are ambiguous. In most documents reviewed in this study, the choice of verb implied agency for industry actors, with 70 instances compared to only six where the verb choice implied agency for community actors (Table 4).

\section{DISCUSSION}

This study explored the public discourse around SLO in New Zealand's marine economy to identify how usage of the term affects power relations between industry, stakeholders, and iwi. There were four key lines of enquiry: defining SLO, approaches for advancing SLO, agency and actors, and status of SLO.

Definitions of social license to operate vary widely in New Zealand's public discourse. Definitions are important for power relations, as those who publicly define a term capture its meaning and influence the public's understanding of the concept (Gaventa 2006). Conversely, failure to define the term leaves it open to interpretation and confusion, and thus mystifies the intentions of those using the term. Of the documents examined for this study, less than a quarter defined SLO, and definitions varied widely with 17 definitional components. These findings corroborate other studies that found that the ways companies define SLO vary and are seldom made explicit, and that key theoretical criteria for SLO are overlooked (see, e.g., Bice 2014). There was no agreed definition of SLO applied consistently in relation to the commercial use of New Zealand's marine environment, and the range of definitions identified in this study suggests that the term is being used rhetorically to suit particular contexts and purposes.

Similarly, we found many approaches for advancing SLO. Although some of the approaches reflect generally agreed attributes for the establishment of SLO such as relationships, trust, and benefits sharing (Thomson and Boutilier 2011, Prno 2013, Boughen et al. 2014, Baines and Edwards 2018), many of the other approaches could be interpreted by communities and iwi as top-down, coercive, or controlling. When peoples' behavioral freedoms are reduced or threatened, they can become motivated to regain their freedoms by rejecting the message and its source, a behavior termed "psychological reactance" (Brehm 1966, Brehm and Brehm 2013). In our study, for example, there were multiple instances of industry describing its approach for advancing SLO as communicating facts to the public to increase their understanding of industry activities. Although genuine communication and engagement is generally cited in the literature as an important criterion for SLO (e.g., Dare et al. 2014), communication styles that emphasize one-way information flow, whether deliberate or inadvertent, are likely to result in a sense of coercion or reduced freedoms in those receiving the messages, i.e., communities and iwi, raising the possibility of public reactance.

Such public reactance may become amplified if communities and iwi feel that their agency over SLO is not acknowledged. Although communities and Indigenous groups theoretically hold agency over SLO, our findings suggest that this is generally not reflected in New Zealand's public discourse about SLO in the marine environment. Central government and industry dominate this discourse and frequently vest explicit agency with industry, not communities, as has been found in other discourse analyses (e.g., Parsons and Moffat 2014). To be fair, industry vesting agency with itself is a form of taking responsibility, and a recognition that SLO cannot be taken for granted just because one has a legal permit. In that sense, industry should have some degree of agency if they are to be an active participant in relationship-building processes. It may become problematic, however, if industry does not explicitly recognize the agency of communities and iwi, or if industry fails to see SLO as a matter of relationships between partners (Baines and Edwards 2018). 
Table 4. Instances of implied social license to operate (SLO) agency as revealed by material process verbs. Iwi = Indigenous Māori tribes of New Zealand

\begin{tabular}{|c|c|c|c|}
\hline & \multicolumn{3}{|c|}{ Implied agent } \\
\hline & Industry & Community & Ambiguous \\
\hline Source & $\begin{array}{l}\text { Achieve, Acquire, Build, Buy, Earn, } \\
\text { Enhance, Establish, Gain, Grow, } \\
\text { Improve, Increase, Lose, Maintain, } \\
\text { Obtain, Preserve, Retain, Strengthen, } \\
\text { Undermine }\end{array}$ & Challenge, Grant, Remove, Withhold & $\begin{array}{l}\text { Create, Engender, Erode, Evaporate, } \\
\text { Foster, Invest, Reinforce, Support }\end{array}$ \\
\hline Central Govt & 27 & 1 & 2 \\
\hline Local Govt & 1 & 0 & 1 \\
\hline Industry & 17 & 2 & 1 \\
\hline NGO & 3 & 1 & 3 \\
\hline Iwi & 1 & 1 & 0 \\
\hline Other & 21 & 1 & 1 \\
\hline Total & 70 & 6 & 8 \\
\hline
\end{tabular}

Indeed, the New Zealand government in 2014 took decisionmaking authority over salmon farms away from a local government authority, while central government ministers talked about the importance of "improving" and "building" social license, ignoring the agency of communities. In this way, the dominant discourse in New Zealand, which primarily vests agency over SLO with industry and government while less frequently acknowledging the agency of communities and iwi, serves to legitimize political moves that render local communities objects of consultation under law, rather than entities that may grant or withhold social license.

Although many large companies now actively consult with Indigenous groups when initiating new projects, the long-term relationship building necessary for the establishment of SLO is not reflected in New Zealand's SLO discourse. Our search not only revealed few documents suggesting that iwi contributed to SLO, but that iwi were also generally absent from the documents in relation to SLO. Similar levels of nonparticipation by Indigenous peoples in public discourse about SLO were found by Parsons and Moffat (2014). This is not always the case, however, particularly where concerted efforts are made by industry to engage constructively and partner with Indigenous groups to explore what SLO might offer in the context of comanagement (Prno 2013). For New Zealand contexts, Ruckstuhl et al. (2014) advocate a "treaty approach" that "provides a well-prepared route by which to adapt the SLO notion ... [so that industry can] ... successfully achieve social licence" (Ruckstuhl et al. 2014:312). According to Ruckstuhl et al., a treaty approach to SLO includes, among other things, ensuring genuine iwi influence in decisionmaking, recognizing Māori values, and recognizing the subtle differences between partner and stakeholder, i.e., treating iwi as a partner. Given this emphasis on the treaty and treaty-derived commercial interests (such as fishing quota), the absence of Māori voices in the SLO discourse might also reflect Māori ambivalence toward this terminology. Likewise, the paucity of references to iwi could be the result of an awareness within government and industry of this sensitivity. Further research exploring these complex relationships would help to illuminate the relevance of SLO to Māori and other indigenous peoples.

In New Zealand's marine SLO discourse, industry and central government frequently imply that companies operating in the marine environment already have SLO, and therefore their objective is to "maintain" or "improve" it. Community interests might ask upon what basis these assertions are made, given the apparent absence of SLO monitoring, reporting, or a mandated body to issue SLO. Indeed, those few community groups and NGOs participating in New Zealand's public discourse of SLO commonly referred to it in negative terms or reject its existence outright. This negative interpretation of SLO has been observed in other studies. Owen and Kemp (2013), for example, argued that while SLO cannot be formally granted by communities, it can be revoked by dissatisfied and vocal community members or groups, which Owen and Kemp conceptualize as a "crude form of 'negative governance"” (Owen and Kemp 2013:4).

A final irony is that those companies talking about SLO are often among the more progressive members of their industry yet find themselves on the horns of a dilemma. If they talk only about what their company does to gain, maintain, or improve SLO, without giving agency to communities, they disempower the groups that the concept of SLO is meant to empower. Yet if they specify the groups the company considers are able to grant SLO, they risk disempowering other groups and the wider public, who might question why the company thinks that it can decide who grants SLO. The public discourse of SLO is thus fraught with complexity for a company genuinely interested in improving the public's acceptance and approval of its operations.

What began in the 1990 s as a metaphor to conceptualize the importance of involving communities in business decision making, the concept of SLO is at risk of being negatively perceived as a tool of corporate coercion. As Hajer and Versteeg (2005) point out, if realities are constituted through discourse and have political consequences, then our discourse analysis ultimately raises the question of how to talk about social license in such a way that its construction is more genuine and democratic. The few community groups and NGOs that have engaged in the discourse have attempted to reclaim this democratic power, asserting their ability to withhold or revoke SLO. These groups, and industry, could each put forward their own definitions and criteria for what constitutes SLO, so that these can be publicly debated and those who claim (or deny) SLO can be held accountable. Industry and government actors, who are most vocal in the SLO discourse, need to identify the basis on which they 
suggest industry might achieve SLO. Otherwise, the concept is likely to remain a rhetorical device that has the potential to disempower and marginalize communities and iwi and therefore does little to achieve real SLO for companies operating in the marine environment.

\section{CONCLUSION}

Over the past decade, the term SLO has gained increasing currency in the public discourse about New Zealand's marine industries. This discourse has been dominated by industry and central government, who frequently vest agency over SLO with industry and state or imply that industry needs to maintain or improve SLO, implying that industry already possesses SLO. Whether inadvertent or intentional, this choice of language empowers industry at the expense of communities and iwi, and carries risks of public rejection of, or reactance to, industry claims to SLO. In the long-term interests of sustainable development and positive industry-community-iwi relations, we encourage those using SLO to reflect deeply on the ways in which their use of the term, however subtle, can affect power relations between the people and parties involved in, and affected by, commercial activities in the marine environment.

Responses to this article can be read online at: http://www.ecologyandsociety.org/issues/responses. $\mathrm{php} / 11304$

\section{Acknowledgments:}

The authors thank the anonymous reviewers whose comments have helped us to sharpen and clarify the paper significantly. Natasha Berkett and Charlotte Šunde contributed to early discussions on methodology, Peter Edwards helped with the document search, and James Baines and Carolyn Lundquist provided comments and suggestions during drafting. This research was funded by New Zealand's Ministry of Business Innovation and Employment through the Sustainable Seas National Science Challenge (Contract CO1X1515).

\section{LITERATURE CITED}

Ahearn, L. M. 2001. Language and agency. Annual Review of Anthropology 30:109-137. https://doi.org/10.1146/annurev.anthro.30.1.109

Aquaculture New Zealand. 2014. The chairman. Aquaculture New Zealand, Nelson, New Zealand. [online] URL: https://www. aquaculture.org.nz/2014/02/21/the-chairman/

Baines, J., and P. Edwards. 2018. The role of relationships in achieving and maintaining a social licence in the New Zealand aquaculture sector. Aquaculture 485:140-146. https://doi. org/10.1016/j.aquaculture.2017.11.047

Banerjee, S. B. 2008. Corporate social responsibility: the good, the bad and the ugly. Critical Sociology 34:51-79. https://doi. org/10.1177/0896920507084623

Bice, S. 2014. What gives you a social licence? An exploration of the social licence to operate in the Australian mining industry. Resources 3:62-80. https://doi.org/10.3390/resources3010062
Billing, S.-L. 2018. Using public comments to gauge social licence to operate for finfish aquaculture: lessons from Scotland. Ocean \& Coastal Management 165:401-415. https://doi.org/10.1016/j. ocecoaman.2018.09.011

Bodwitch, H. 2017. Challenges for New Zealand's individual transferable quota system: processor consolidation, fisher exclusion, \& Māori quota rights. Marine Policy 80:88-95. https:// doi.org/10.1016/j.marpol.2016.11.030

Boughen, N., J. Parr, A. Littleboy, S. Johns, P. Ashworth, and C. Yeats. 2008. Future mining of the Australian seafloor-do we have the social licence? In International future mining conference and exhibition. The University of New South Wales, Sydney, Australia.

Boughen, N., K. Moffat, and A. Zhang. 2014. Trust - a central element of mining's social licence. AusIMM Bulletin 68(6):70-71.

Boutilier, R. G. 2014. Frequently asked questions about the social licence to operate. Impact Assessment and Project Appraisal 32:263-272. https://doi.org/10.1080/14615517.2014.941141

Brehm, J. W. 1966. A theory of psychological reactance. Academic, Oxford, UK.

Brehm, S. S., and J. W. Brehm. 2013. Psychological reactance: a theory of freedom and control. Academic, New York, New York, USA.

Collaboration for Environmental Evidence. 2013. Guidelines for systematic reviews in environmental management. Version 4.2. Centre for Evidence-Based Conservation, Bangor University, Bangor, UK. [online] URL: http://www.environmentalevidence. org/Documents/Guidelines/Guidelines4.2.pdf

Conn, V., J. Valentine, H. Cooper, and M. Rantz. 2003. Grey literature in meta-analyses. Nursing Research 52:256-261. https:// doi.org/10.1097/00006199-200307000-00008

Cope, M. 2010. Coding qualitative data. Pages 281-294 in I. Hay, editor. Qualitative research methods in human geography. Third edition. Oxford University Press, Oxford, UK.

Cullen-Knox, C., A. Fleming, L. Lester, and E. Ogier. 2019. Publicised scrutiny and mediatised environmental conflict: the case of Tasmanian salmon aquaculture. Marine Policy 100:307-315. https://doi.org/10.1016/j.marpol.2018.11.040

Cullen-Knox, C., M. Haward, J. Jabour, E. Ogier, and S. R. Tracey. 2017. The social licence to operate and its role in marine governance: insights from Australia. Marine Policy 79:70-77. https://doi.org/10.1016/j.marpol.2017.02.013

Dare, M., J. Schirmer, and F. Vanclay. 2014. Community engagement and social licence to operate. Impact Assessment and Project Appraisal 32:188-197. https://doi.org/10.1080/14615517.2014.927108

Dryzek, J. S. 2013. The politics of the earth: environmental discourses. Oxford University Press, Oxford, UK.

Edwards, P., J. Lacey, S. Wyatt, and K. J. H. Williams. 2016. Social licence to operate and forestry-an introduction. Forestry: An International Journal of Forest Research 8(5):473-476. https://doi. org/10.1093/forestry/cpw036 
Edwards, P., and S. Trafford. 2016. Social licence in New Zealand - What is it? Journal of the Royal Society of New Zealand 46:165-180. https://doi.org/10.1080/03036758.2016.1186702

Fairclough, N. 2013. Critical discourse analysis: the critical study of language. eBook. Routledge, London, UK. https://doi. org/10.4324/9781315834368

Fleming, P., and M. T. Jones. 2013. The end of corporate social responsibility: crisis and critique. SAGE, Los Angeles, California, USA.

Gaventa, J. 2006. Finding the spaces for change: a power analysis. IDS Bulletin 37:23-33. https://doi.org/10.1111/j.1759-5436.2006. $\underline{\text { tb00320.x }}$

Grutzner, J., and E. Salim. 2003. Striking a better balance: The World Bank Group and extractive industries (English). Extractive industries review. World Bank Group, Washington, D.C., USA. [online] URL: http://documents.worldbank.org/curated/ en/222871468331889018/The-World-Bank-Group-and-extractiveindustries

Gunningham, N., R. A. Kagan, and D. Thornton. 2004. Social license and environmental protection: why businesses go beyond compliance. Law \& Social Inquiry 29:307-341. https://doi. org/10.1111/j.1747-4469.2004.tb00338.x

Hajer, M., and W. Versteeg. 2005. A decade of discourse analysis of environmental politics: achievements, challenges, perspectives. Journal of Environmental Policy \& Planning 7:175-184. https://doi. org/10.1080/15239080500339646

Hall, N. L. 2014. The discourse of "social licence to operate": case study of the Australian wind industry. AIMS Energy 2:443-460. https://doi.org/10.3934/energy.2014.4.443

Halliday, M. A. K., and C. M. I. M. Matthiessen. 2013. Halliday's introduction to functional grammar. Routledge, London, UK. https://doi.org/10.4324/9780203431269

Hamann, R., and P. Kapelus. 2004. Corporate social responsibility in mining in Southern Africa: fair accountability or just greenwash? Development 47(3):85-92. https://doi. org/10.1057/palgrave.development.1100056

Harvey, B., and S. Bice. 2014. Social impact assessment, social development programmes and social licence to operate: tensions and contradictions in intent and practice in the extractive sector. Impact Assessment \& Project Appraisal 32:327-335. https://doi. org/10.1080/14615517.2014.950123

Harwood, A. 1988. A discussion about "discourse." Medical Anthropology Quarterly 2:99-101. https://doi.org/10.1525/ $\underline{\text { maq.1988.2.2.02a00010 }}$

Hobday, A. J., L. E. Chambers, and J. P. Y. Arnould. 2015. Prioritizing climate change adaptation options for iconic marine species. Biodiversity Conservation 24:3449-3468. https://doi. org/10.1007/s10531-015-1007-4

Iwi Collective Partnership. 2016. The inconvenient truth of Māori fisheries. Iwi Collective Partnership, Mount Wellington, New Zealand.

Kelly, R., G. T. Pecl, and A. Fleming. 2017. Social licence in the marine sector: a review of understanding and application. Marine Policy 81:21-28. https://doi.org/10.1016/j.marpol.2017.03.005
Kos, K. 2015. Teaching our children about seafood. Seafood New Zealand, Wellington, New Zealand. [online] URL: https://www. seafood.org.nz/media/news/news/?tx ttnews $\% 5$ Btt news $\%$ 5D=247\&cHash $=$ e34b7ed93caf042d9eaf4697df30287d

Lacey, J., P. Edwards, and J. Lamont. 2016. Social licence as social contract: procedural fairness and forest agreement-making in Australia. Forestry: An International Journal of Forest Research 89:489-499. https://doi.org/10.1093/forestry/cpw027

Leith, P., E. Ogier, and M. Haward. 2014. Science and social license: defining environmental sustainability of Atlantic salmon aquaculture in south-eastern Tasmania, Australia. Social Epistemology 28(3-4):277-296. https://doi.org/10.1080/02691728.2014 .922641

Mather, C., and L. Fanning. 2019. Social licence and aquaculture: towards a research agenda. Marine Policy 99:275-282. https://doi. org/10.1016/j.marpol.2018.10.049

McGuinness Institute. 2016. New Zealand King Salmon: a financial perspective. Working Paper 2016/02. The McGuinness Institute, Wellington, New Zealand. [online] URL: http://www. mcguinnessinstitute.org/wp-content/uploads/2017/05/20170519-WorkingPaper-201602-NZKS-A-financial-perspective-Final.pdf

McKenna, B. 2004. Critical discourse studies: where to from here? Critical Discourse Studies 1(1):9-39. https://doi.org/10.1080/174$\underline{05900410001674498}$

McPhee, R. 2015. Update on the business growth agenda: towards 2025 report. Northland Regional Council Regulatory and Environment Committee, Whangārei, New Zealand.

Meesters, M. E., and J. H. Behagel. 2017. The social licence to operate: ambiguities and the neutralization of harm in Mongolia. Resources Policy 53:274-282. https://doi.org/10.1016/j. resourpol.2017.07.006

Ministry for Business, Innovation, \& Employment (MBIE). 2015. Sustainable Seas. Ko ngā moana whakauka. National Science Challenge Research and Business Plan. MBIE, Wellington, New Zealand. [online] URL: http://sustainableseaschallenge.co.nz/ sites/default/files/2016-05/Sustainable $\% 20$ Seas $\% 20$ Research $\% 20 \mathrm{Plan} \%$ 20- $\% 2030 \% 20$ September $\% 202015$.pdf

Ministry for Primary Industries (MPI). 2014. Briefing for incoming ministers. MPI, Wellington, New Zealand.

Ministry for Primary Industries (MPI). 2016. Te Huapae Mataora Mo Tangaroa. The future of our fisheries. Volume III: integrated electronic monitoring and reporting system. MPI, Wellington, New Zealand. [online] URL: https://www.mpi.govt.nz/dmsdocument/14668/ loggedIn

Minter Ellison Rudd Watts. 2012. Top ten trends facing the mining industry - a legal perspective. March 2012. Minter Ellison Rudd Watts, Auckland, New Zealand. [online] URL: http://www. nzresources.com/attachments/3142/me.pdf

Moffat, K., J. Lacey, A. Zhang, and S. Leipold. 2016. The social licence to operate: a critical review. Forestry: An International Journal of Forest Research 89:477-488. https://doi.org/10.1093/ forestry/cpv044

Moffat, K., and A. Zhang. 2014. The paths to social licence to operate: an integrative model explaining community acceptance 
of mining. Resources Policy 39:61-70. https://doi.org/10.1016/j. resourpol.2013.11.003

National Science Challenges Panel. 2013. Report of National Science Challenges Panel. Ministry of Business Innovation and Employment, Wellington, New Zealand. [online] URL: https:// www.pmcsa.org.nz/wp-content/uploads/Report-of-National-ScienceChallenges.pdf

New Zealand Oil \& Gas. 2015. Annual report. New Zealand Oil \& Gas, Wellington, New Zealand. [online] URL: https://www. nzog.com/dmsdocument/146

Ocean Governance. 2018. Blue economy. Ocean Governance. [online] URL: http://www.earthsystemgovernance.net/oceans/? page $\mathrm{id}=79$

Owen, J. R., and D. Kemp. 2013. Social licence and mining: a critical perspective. Resources Policy 38:29-35. https://doi. org/10.1016/j.resourpol.2012.06.016

Parsons, R., J. Lacey, and K. Moffat. 2014. Maintaining legitimacy of a contested practice: how the minerals industry understands its 'social licence to operate.' Resources Policy 41:83-90. https://doi.org/10.1016/j.resourpol.2014.04.002

Parsons, R., and K. Moffat. 2014. Constructing the meaning of social licence. Social Epistemology 28:340-363. https://doi. org/10.1080/02691728.2014.922645

Phillips, N. and C. Hardy. 2002. Discourse analysis: investigating processes of social construction Qualitative Research Methods Series, Vol. 50. SAGE, Thousand Oaks, California, USA.

Ports of Auckland Limited. 2016. Final statement of corporate intent. For the period from 1 July 2016 to 30 June 2019. Ports of Auckland Limited, Auckland, New Zealand.

Prno, J. 2013. An analysis of factors leading to the establishment of a social licence to operate in the mining industry. Resources Policy 38:577-590. https://doi.org/10.1016/j.resourpol.2013.09.010

QSR International Pty Ltd. 2015. NVivo 11 Qualitative Data Analysis Software. QSR International, Melbourne, Australia.

Quigley, R., and J. Baines. 2014. How to improve your social licence to operate. A New Zealand industry perspective. Ministry for Primary Industries, Wellington, New Zealand.

Richert, C., A. Rogers, and M. Burton. 2015. Measuring the extent of a social license to operate: the influence of marine biodiversity offsets in the oil and gas sector in Western Australia. Resources Policy 43:121-129. https://doi.org/10.1016/j. resourpol.2014.12.001

Ruckstuhl, K., M. Thompson-Fawcett, and H. Rae. 2014. Māori and mining: Indigenous perspectives on reconceptualising and contextualising the social licence to operate. Impact Assessment and Project Appraisal 32:304-314. https://doi.org/10.1080/14615$\underline{517.2014 .929782}$

Seafood New Zealand. 2014. Friday update. Seafood New Zealand, Wellington, New Zealand.

Smits, C. C. A., J. van Leeuwen, and J. P. M. van Tatenhove. 2017. Oil and gas development in Greenland: a social license to operate, trust and legitimacy in environmental governance. Resources Policy 53:109-116. https://doi.org/10.1016/j.resourpol.2017.06.004
Sustainable Business Council. 2013. Social licence to operate paper. Sustainable Business Council, Wellington, New Zealand. [online] URL: https://www.sbc.org.nz/ data/assets/pdf file/0005/99437/ Social-Licence-to-Operate-Paper.pdf

Sustainable Seas. 2015. Sustainable seas. Ko ngā moana whakauka. National Science Challenge. [online] URL: https://tethys.pnnl. gov/sites/default/files/publications/hall-et-al-2015.pdf

Thomson, I., and R. G. Boutilier. 2011. Social license to operate. Pages 1-10 in P. Darling, editor. SME mining engineering handbook. Society for Mining, Metallurgy and Exploration, Littleton, Colorado, USA.

Tollefson, C., and R. Scott. 2006. Charting a course: shellfish aquaculture and Indigenous rights in New Zealand and British Columbia. BC Studies 150:3-41.

Voyer, M., W. Gladstone, and H. Goodall. 2015. Obtaining a social licence for MPAs-influences on social acceptability. Marine Policy 51:260-266. https://doi.org/10.1016/j.marpol.2014.09.004

Waitt, G. 2010. Doing Foucauldian discourse analysis - revealing social realities. Pages 217-240 in I. Hay, editor. Qualitative methods in human geography. Oxford University Press, Oxford, UK.

Williams, J., and P. Martin, editors. 2011. Defending the social licence of farming: issues, challenges and new directions for agriculture. CSIRO, Collingwood, Australia. https://doi. org/10.1071/9780643104549

Wilson, J. 2018. Nation and government - The origins of nationhood. In Te Ara - the Encyclopedia of New Zealand. Manatū Taonga Ministry for Culture and Heritage, Wellington, New Zealand. [online] URL: http://www.TeAra.govt.nz/en/document/4216/ the-three-articles-of-the-treaty-of-waitangi 